\title{
Six years too long
}

\section{Editorial by THE TIMES OF PAPUA NEW GUINEA}

\section{October 1994}

THIS WEEK'S peace talks in Arawa are finally taking place despite a no show of the leaders of the Bougainville Revolutionary Army or the Bougainville Interim Government. The rest of the island has turned and is now awaiting the appearance of representatives of these two groups before any meaningful round of talks can begin. The national Government has gone with its agenda, which among other things includes amnesty, reconciliation, compensation, restoration, the future of the Panguna mine, the future of the security forces on the island and the border treaty between Papua New Guinea and the Solomon Islands.

Representatives of BRA and BIG no doubt have their own agenda, and their priorities may not necessarily be the same as that of the national Government.

The crucial issue though, is that of Bougainville's political future. This is the crux of the peace talks as far as the hardline separatists are concerned. Talks surrounding this matter were die to start yesterday, Wednesday, however, because of the no show by the representatives of the BRA and BIG, it will have to be rescheduled. It is not a light matter and more time needs to be given so that each side is clear on where it stands and there are no misunderstandings.

That aside, the reaction from the many thousands of people who have made their way to the Arawa peace talks since the weekend have one feeling in common and have publicly stated that view - they want to see an end to the conflict and have peace return to the island so they can get on with their lives.

Six years is too long to ask any group of people to put up with a conflict hat does not have any end in sight other than prolonging the destruction to their lives. It is a conflict that does not have popular support as it once did.

This will be the first time for the BRA and BIG to come forward to address the people of the North Solomons whose interest they claim to represent. And this is maybe the only chance these people have of telling their self-appointed leaders what exactly they think of being caught in between.

Six days have been set for this conference. It may appear to be too short a time to discuss vital issues. However, it should not be too short - for the 
